\title{
PERLINDUNGAN HUKUM TERHADAP PARA PIHAK YANG DIRUGIKAN ATAS PENYULUHAN HUKUM OLEH NOTARIS
}

\author{
Ferdiansyah Putra \\ Magister Kenotariatan Fakultas Hukum Universitas Narotama Surabaya \\ Email : ferdiansyah.aan2018@gmail.com \\ Ghansham Anand \\ Magister Kenotariatan Fakultas Hukum Universitas Narotama Surabaya \\ Universitas Airlangga Surabaya \\ Email : gansam_anand@ymail.com
}

\begin{abstract}
ABSTRAK
Pasal 15 ayat (2) huruf e Undang-Undang Jabatan Notaris (UUJN) memberikan kewenangan bagi Notaris untuk memberikan penyuluhan hukum sehubungan dengan pembuatan akta, artinya Notaris berwenang memberikan penyuluhan hukum sehubungan dengan akta yang di buatnya. Berkaitan dengan kewenangan tersebut dapat terjadi permasalahan jika dikemudian hari penyuluhan hukum yang diberikan oleh Notaris tersebut kemudian di tindak lanjuti oleh para pihak dalam pembuatan akta namun ternyata akta tersebut dinyatakan batal dan bertentangan dengan Peraturan Perundang-Undangan.

Penulis dalam penelitian ini ingin menelaah dan menganalisa lebih lanjut tentang bentuk penyuluhan hukum oleh Notaris serta tanggung gugat Notaris atas penyuluhan hukum yang merugikan para pihak

Metode penelitian yang digunakan adalah penelitian hukum normatif, yaitu penelitian hukum yang dilakukan dengan cara meneliti bahan pustaka atau bahan hukum sekunder sedangkan pendekatan masalah dilakukan dengan menggunakan pendekatan undang-undang dan pendekatan konseptual.

Hasil penelitian menunjukkan bahwa bentuk penyuluhan hukum yang dapat dilakukan oleh Notaris hanya sebatas pada hal yang berkaitan dengan pembuatan akta saja. Notaris dalam memberikan penyuluhan hukum harus memahami substansi permasalahan yang akan diberikan penyuluhan sehingga mampu memberikan solusi yang benar. Notaris hanya sebatas memberikan penyuluhan hukum kepada para pihak namun hasil akhirnya dikembalikan kepada para pihak untuk membuat perjanjian tersebut sehingga Notaris tidak dapat dimintakan tanggung gugat atas kerugian para pihak.
\end{abstract}

Kata Kunci : Notaris, Penyuluhan Hukum, Tanggung Gugat

\section{ABSTRACT}

Article 15 section 2e Legal Constitution of Notary Public Profession (UUJN) provides authority for notary public to conduct legal counseling in related to publishing deed. In other words, notary public has authority to provide legal counseling about notarial deed. Concerning this authority, issue that might be occurred in the future is when the counseling given by notary public is regarded as breaching and the notarial deed is canceled by the court.

The present study aims to examine and elaborate further about counseling material 
conducted by notary public coupled with accountability of notary public in related to legal protection of aggrieved parties in related to the legal counseling conducted by notary public.

The method used in the present study is a normative legal research, namely legal research which is conducted by examining the library materials or secondary law while in finding and collecting the data is done by two approaches, namely the law and conceptual approaches.

The present study concluded that notary public only has authorization in conducting legal counseling concerning publication of notarial deed. Notary public in providing legal counseling shall comprehend substantial issue that is discussed in order to provide proper solution concerning the issue. Despite the outcome of the counseling will be applied or not it depends on the parties that consult to the notary public. Notary public cannot be asked for accountability for all losses that are experienced by the parties.

Keywords: Notary Public, Legal Counseling, Accountability

\section{Pendahuluan}

Peran Notaris dalam sektor pelayanan jasa adalah sebagai pejabat yang diberi wewenang oleh negara untuk melayani masyarakat dalam bidang perdata khususnya pembuatan akta otentik sebagaimana disebutkan dalam Pasal 1 ayat (1) Undang-Undang Nomor 30 Tahun 2004 Tentang Jabatan Notaris sebagaimana telah diubah dengan Undang-Undang Nomor 2 Tahun 2014 Tentang Perubahan Atas UndangUndang Nomor 30 Tahun 2004 Tentang Jabatan Notaris (UUJN) yang menyatakan bahwa Notaris adalah pejabat umum yang berwenang untuk membuat akta otentik dan kewenangan lainnya sebagaimana dimaksud dalam undang-undang ini. Landasan filosofis dibentuknya UUJN adalah terwujudnya jaminan kepastian hukum, ketertiban dan perlindungan hukum yang berintikan kebenaran dan keadilan melalui akta yang dibuatnya, Notaris harus dapat memberikan kepastian hukum kepada masyarakat pengguna jasa Notaris.

Produk hukum yang dikeluarkan oleh Notaris adalah berupa akta-akta yang memiliki sifat otentik dan memiliki kekuatan pembuktian yang sempurna.
Berdasarkan ketentuan Pasal 1868 Burgerlijk Wetboek (BW) dirumuskan bahwa suatu akta otentik ialah suatu akta yang di dalam bentuk yang ditentukan oleh undang-undang, dibuat oleh atau dihadapan pegawai-pegawai umum yang berkuasa untuk itu ditempat dimana akta dibuatnya.

Menurut Habib Adjie, pengertian pejabat umum dijelaskan oleh Pasal 1 angka 1 UUJN adalah Notaris sebagai pejabat umum, selanjutnya pengertian berwenang meliputi berwenang terhadap orangnya, yaitu untuk kepentingan siapa akta itu dibuat atau dikehendaki oleh orang yang berkepentingan. Berwenang terhadap aktanya, yaitu yang berwenang membuat akta otentik mengenai semua perbuatan, perjanjian dan ketetapan yang diharuskan Undang-Undang atau yang dikehendaki yang bersangkutan, serta berwenang terhadap waktunya dan berwenang terhadap tempatnya, yaitu sesuai tempat kedudukan dan wilayah Jabatan Notaris dan Notaris menjamin kepastian waktu para penghadap yang tercantum dalam akta (Habib Adjie;2009).

Selain memenuhi syarat yang telah ditentukan Undang-Undang agar suatu 
akta menjadi otentik, seorang Notaris dalam melaksanakan tugasnya tersebut wajib. Melaksanakan tugasnya dengan penuh disiplin, professional dan integritas moralnya tidak boleh diragukan, apa yang tertuang dalam awal dan akhir akta yang menjadi tanggungjawab notaris adalah ungkapan yang mencerminkan keadaan yang sebenar-benarnya pada saat pembuatan akta (Tan Thong Kie;2000).

Dalam menjalankan jabatannya secara profesional dirasakan semakin penting karena kedudukan notaris sebagai pejabat umum berhadapan langsung dengan kepentingan masyarakat dalam memberikan bantuan pelayanan atau jasa. Apabila hal tersebut tidak diberikan secara baik atau profesional, maka nantinya terdapat pihak yang dirugikan sebagai akibat hukum dari kesalahan atau kelalaian yang telah diperbuat oleh notaris.

Apabila berbicara mengenai kemampuan professional para notaris, maka erat kaitannya dengan masalah mutu pelayanan jasa hukum notaris kepada masyarakat. Semakin meningkat kemampuan professional para notaris dalam melaksanakan tugasnya sebagai pejabat umum yang mempunyai fungsi mengatur hubungan hukum di antara para pihak secara tertulis dan otentik, akan semakin baik pula mutu pelayanan jasa hukum yang akan diterima masyarakat. Kemampuan professional seseorang yang menunjuk pada keahlian didukung oleh penguasaan ilmu, pengalaman dan keterampilan yang tinggi.

Notaris dalam menjalankan tugas jabatannya harus memiliki sikap yang adil. Adil yang dimaksud ialah tidak ada keberpihakan terhadap siapapun, terutama menyangkut akta yang akan dibuat dihadapannya (Guntur Iskandar;2013). Selain itu dalam menjalankan tugas jabatannya diharapkan mampu memberikan suatu penyuluhan hukum terkait pembuatan akta kepada para penghadap agar para penghadap mampu memahami apa yang menjadi hak dan kewajibannya pada saat akta telah ditandatangani dengan sempurna. Disisi lain penyuluhan hukum oleh Notaris diharapkan mampu mengurangi terjadinya kesalahan pemahaman di masyarakat dalam pembuatan akta otentik oleh masyarakat.

Berkaitan dengan pemberian penyuluhan hukum oleh notaris, telah diatur pula dalam ketentuan Pasal 15 ayat (2) huruf e UUJN, bahwa notaris berwenang memberikan penyuluhan hukum dan penjelasan-penjelasan kepada pihak-pihak yang berkepentingan sehubungan dengan pembuatan akta autentik yang akan, sedang dan/atau dibuat sampai sempurnanya akta. Makna pemberian penyuluhan hukum oleh notaris sehubungan dengan pembuatan akta autentik dalam ketentuan Pasal 15 ayat (2) huruf e UUJN mengakibatkan terjadinya ketidakjelasan/kekaburan norma mengenai kewenangan notaris.

Masih dalam kaitannya dengan kewenangan Notaris untuk memberikan penyuluhan hukum, adanya kekaburan norma dalam pemaknaan kewenangan Notaris untuk memberikan penyuluhan hukum melahirkan suatu pertanyaan bagaimana bentuk tanggung gugat Notaris apabila dikemudian hari penyuluhan hukum yang diberikan oleh Notaris ternyata tidak sesuai dengan Peraturan Perundang-Undangan yang ada sehingga membawa implikasi akta yang dibuat oleh para pihak tersebut dinyatakan batal dan akhirnya merugikan para pihak.

\section{Rumusan Masalah}


1. Apa bentuk penyuluhan hukum oleh Notaris?

2. Apa tanggung gugat Notaris atas penyuluhan hukum yang merugikan para pihak?

\section{Metode Penelitian}

Penelitian ini menggunakan metode penelitian hukum normatif yang dilakukan untuk mencari pemecahan masalah atas permasalahan hukum yang ada. Pendekatan penelitian yang digunakan adalah pendekatan undangundang (statute approach) dan pendekatan konseptual (conceptual approach).

\section{Pembahasan}

\section{Kewenangan Notaris Dalam \\ Memberikan Penyuluhan Hukum}

Penyuluhan hukum merupakan bagian dari pembangunan hukum nasional, sedangkan pembangunan hukum nasional bagian dari pembangunan nasional. Kegiatan penyuluhan hukum merupakan salah satu sosialisasi untuk menggambarkan bagaimana itu keadilan. Hukum nasional tidak bisa penjamin terwujudnya keadilan itu (SUDJIT0;2008).

Kata "penyuluhan"

secara etimologis memiliki makna (a) proses, cara, perbuatan menyuluh; penerangan; dan (c) pengintaian; penyelidikan (Departemen Pendidikan Dan Kebudayaan;1985). Penyuluhan adalah turunan dari kata exstension yang dipakai secara luas dan umum dalam bahasa Indonesia. Penyuluhan berasal dari kata dasar suluh yang berarti pemberi terang ditengah kegelapan. Dalam bahasa Belanda penyuluhan disebut Voorlichting yang berarti memberi penerangan untuk menolong seseorang menemukan jalannya, dalam bahasa Inggris dan Jerman mengistilahkan penyuluhan sebagai pemberian saran atau Beratung yang berarti seseorang dapat memberikan petunjuk bagi seseorang tetapi seseorang tersebut yang berhak untuk menentukan

(Prasetyo;2016).

Adapun fungsi dari penyuluhan hukum adalah langkah pencegahan, langkah korektif, langkah pemeliharaan dan fungsi pengembangan. Pertama, penyuluhan sebagai langkah pencegahan (preventif), yakni mencegah timbulnya hak-hak yang negatif dan desdruktif yang dapat mengakibatkan kerugian bagi masyarakat. Kedua, penyuluhan sebagai langkah korektif, yakni berfungsi sebagai koreksi terhadap hal- hal yang telah ada, sehingga apabila terdapat suatu hal yang melanggar hukum dapat mengurangi dampak ataupun menghilangkan hal tersebut. Ketiga, penyuluhan sebagai langkah pemeliharaan (presevatif), yakni memberikan dorongan untuk menumbuhkan semangat supaya berpartisipasi dalam pembangunan hukum sesuai dengan kemampuan dan kedudukannya masing-masing. Keempat, penyuluhan sebagai fungsi pengembangan (developmental), yakni memberikan dorongan dan masukan terhadap suatu hal agar masyarakat dapat lebih mandiri dan tidak tergantung ataupun mengandalkan pihak lain (Laurensius).

Pengertian tentang penyuluhan hukum juga disebutkan dalam beberapa Peraturan Perundang-Undangan. Pada Pasal 1 angka 1 Peraturan Menteri Pendayagunaan Aparatur Negara dan Reformasi Birokrasi Republik Indonesia Nomor 3 Tahun 2014 tentang Jabatan Fungsional Penyuluh Hukum dan Angka Kreditnya, disebutkan bahwa penyuluhan hukum adalah kegiatan penyebarluasan informasi hukum dan pemahaman terhadap norma hukum 
dan peraturan perundang-undangan yang berlaku, serta pengembangan kualitas penyuluhan hukum guna mewujudkan dan mengembangkan kesadaran hukum masyarakat sehingga tercipta budaya hukum dalam bentuk tertib dan taat ataupatuh terhadap norma hukum dan peraturan perundang-undangan yang berlaku demi tegaknya supremasi hukum.

Berdasarkan kepada pengertian penyuluhan hukum tersebut, terdapat beberapa unsur pokok dari penyuluhan hukum, yaitu bahwa penyuluhan hukum : a) Kegiatan penyebarluasan informasi hukum; b)Pemberian pemahaman terhadap norma-norma hukum dan peraturan perundang-undangan yang berlaku; c) Pengembangan kualitas penyuluhan hukum guna mewujudkan dan mengembangkan kesadaran hukum masyarakat; d ) Menciptakan budaya hukum masyarakat dalam bentuk tertib dan taat atau patuh tehadap norma hukum dan peraturan perundangundangan yang berlaku demi tegaknya supremasi hukum (www.bphn.go.id).

Pasal 1 Peraturan Menteri Hukum dan Hak Asasi Manusia Nomor M01.PR.08.10 Tahun 2007 tentang Perubahan Atas Peraturan Menteri Hukum dan Hak Asasi Manusia Nomor M-01.PR.08.10 Tahun 2006 tentang Pola Penyuluhan Hukum, Penyuluhan hukum didefinisikan sebagai salah satu kegiatan penyebarluasan informasi dan pemahaman terhadap norma hukum dan peraturan perundangundangan yang berlaku guna mewujudkan dan mengembangkan kesadaran hukum masyarakat sehingga tercipta budaya hukum dalam bentuk tertib dan taat atau patuh terhadap norma hukum dan peraturan perundang-undangan yang berlaku demi tegaknya supremasi hukum.
Tujuan utama dari kegiatan penyuluhan hukum ini pada intinya agar masyarakat tahu hukum, paham hukum, sadar hukum, untuk kemudian patuh pada hukum tanpa paksaan, tetapi menjadikannya sebagai suatu kebutuhan. Pemahaman seseorang tentang hukum beraneka ragam dan sangat tergantung pada apa yang diketahui dari pengalaman yang dialaminya tentang hukum, tetapi masyarakat mengetahu fungsi hukum untuk melayani masyarakat Nofiardi;2015;52).

Notaris sebagai pejabat umum merupakan suatu jabatan yang menjalankan sebagian tugas negara dalam bidang hukum keperdataan dengan kewenangan untuk membuat alat bukti berupa akta autentik atas permintaan para pihak yang datang menghadap Notaris. Sehingga harus dipahami dan dimengerti, notaris dalam menjalankan jabatannya merupakan sebagian tugas negara yang mempunyai kewenangan utama untuk membuat akta autentik atas permintaan para pihak digunakan sebagai alat bukti yang sempurna, dalam hal ini notaris diperkenankan untuk memberikan penyuluhan hukum sehubungan dengan pembuatan akta autentik demi tercapainya kepastian hukum agar sesuai dengan ketentuan peraturan perundang-undangan yang berlaku.

Notaris membuat akta otentik yang merupakan alat pembuktian terkuat dan terpenuh yang mempunyai peranan penting dalam setiap hubungan hukum dalam setiap kehidupan masyarakat. Dalam berbagai hubungan bisnis, perbankan, kegiatan sosial, dan lain-lain, kebutuhan akan pembuktian tertulis berupa akta otentik makin meningkat sejalan dengan berkembangnya tuntutan akan kepastian hukum dalam berbagai kegiatan ekonomi dan sosial, 
baik pada tingkat nasional maupun internasional. Dengan demikian tugas seorang notaris adalah mengkonstantir hubungan hukum antara para pihak dalam bentuk tertulis dan format tertentu, sehingga merupakan suatu akta otentik.

Penghadap datang ke notaris agar tindakan atau perbuatan hukumnya diformulasikan ke dalam akta otentik sesuai dengan kewenangan notaris, kemudian notaris membuatkan akta atas permintaan atau keinginan para penghadap tersebut, maka dalam hal ini memberikan landasan kepada notaris dan para penghadap telah terjadi hubungan hukum. Notaris harus menjamin bahwa akta yang dibuat tersebut telah sesuai menurut aturan hukum yang sudah ditentukan, sehingga kepentingan yang bersangkutan terlindungi dengan adanya akta tersebut (Roenastiti Prayitno;1989). Notaris berdasarkan ketentuan perundangundangan ditugaskan untuk membuat akta yang benar yang dikehendaki oleh undang-undang. Penyuluhan hukum atau penjelasan mengenai ketentuan undang-undang ini diberikan dalam rangka membantu dalam pembuatan akta yang diperlukan dan ini merupakan suatu kesatuan yang tidak dapat dipisahkan satu dengan yang lainnya (Roenastiti Prayitno).

Menurut Hatta Isnaini Wahyu Utomo, mengenai pemberian penyuluhan hukum oleh notaris kepada para pihak yang berkepentingan sehubungan dengan pembuatan akta autentik yang akan dibuat lebih mengarah kepada nasehat untuk memberikan pemahaman hukum terkait perbuatan hukum yang akan dituangkan ke dalam Akta. Dalam hal ini Notaris memberikan pemahaman kepada para pihak terkait ketentuan-ketentuan dalam Peraturan Perundang-Undangan yang berhubungan dengan perbuatan hukum yang akan dilakukan oleh para pihak. Dengan adanya pemahaman hukum yang diberikan oleh notaris diharapkan dapat terciptanya kepastian hukum sesuai dengan ketentuan peraturan perundang-undangan yang berlaku serta memberikan manfaat bagi para pihak. Meskipun pemahaman hukum yang diberikan oleh Noteris tersebut kemudian diterima oleh para pihak, namun pada akhirnya pemahaman hukum yang didapat oleh para pihak dari Notaris tersebut tetap menjadi keterangan para pihak dan menjadi tanggung jawab para pihak sepenuhnya (Wahyu Utomo;2018).

Penyuluhan hukum yang harus diberikan oleh seorang notaris harus berdasarkan keyakinan dalam bidang yang dikuasai dan dalam batas-batas kemampuannya. Keahlian hukum dalam bidangnya harus sesuai dengan peraturan perundang-undangan yang berlaku. Peraturan-peraturan ini merupakan pedoman apa yang boleh dan apa yang tidak boleh dilakukan oleh seorang Notaris dalam pembuatan akta. Inilah salah satu faktor yang membedakan pekerjaan notaris dengan pekerjaan praktisi-praktisi hukum yang lain. Kedudukan Notaris sebagai suatu jabatan yang terhormat dan memiliki peran sangat penting dalam masyarakat tentunya mengharuskan siapa yang memangku jabatan tersebut memiliki kualitas yang mumpuni baik secara keilmuan maupun kepemimpinan.

Ilmu pengetahuan khususnya di bidang hukum harus benar-benar dipahami oleh Notaris secara mendalam. Hal tersebut tercermin dari salah satu syarat pengangkatan Notaris yang disebutkan dalam Pasal 3 huruf e UUJN adalah "Berijazah Sarjana Hukum dan lulus jenjang strata dua Kenotariatan". Adanya kualifikasi khusus tentang 
pendidikan minimal bagi syarat pengangkatan Notaris seperti yang telah disebutkan diatas yaitu Sarjana Hukum dan jenjang strata dua kenotariatan yang lazim disebut dengan Magister Kenotariatan bukan tanpa alasan, hal tersebut ditujukan agar Notaris menjadi sosok yang mampu menyampaikan kebenaran dan memberikan keadilan bagi pihak yang membutuhkan jasanya, bukan sekedar memberikan kepastian hukum semata (Rusdianto;2017).

Notaris yang memberikan penyuluhan hukum dapat disamakan dengan memberikan suatu nasihat hukum karena dalam memberikan suatu penyuluhan hukum maupun nasihat hukum, notaris dalam hal ini memberikan suatu petunjuk atau penjelasan dalam bidang hukum yang sedang dihadapi atau dibutuhkan oleh para penghadap. Pemberian penyuluhan hukum oleh notaris dapat mempengaruhi para pihak dalam menentukan pilihan untuk menentukan tindakan hukumnya (Budiono;1999;63). Mengenai penerapan asas kebebasan berkontrak sepenuhnya tergantung pada para pihak untuk menentukan pilihannya, sedangkan notaris menjaga rambu-rambu (Budiono;1999).

UUJN memberikan kewenangan kepada notaris untuk memberikan penyuluhan hukum sehubungan dengan pembuatan akta dengan tujuan agar para pihak dapat memahami hukum yang berlaku, sehingga hukum tersebut dapat melembaga dan bahkan menjiwai setiap para pihak yang bersangkutan. Tujuannya bukan sekedar memberikan informasi atau keterangan-keterangan mengenai hukum yang perlu diketahui, akan tetapi mengusahakan untuk membina dan meningkatkan kesadaran hukum para pihak yang bersangkutan, sehingga timbul kepatuhan dan ketaatan hukum, atas dasar anggapan bahwa hukum itu sesuai dengan nilai-nilai yang berlaku atau yang dianutnya.

Atas dasar kewenangan tersebut, dalam menjalankan tugas dan kewajibannya notaris dituntut untuk memberikan jaminan kepastian hukum dan pelayanan yang profesional. Dalam mewujudkan 2 (dua) sisi pekerjaan yang mengandung banyak resiko tersebut diperlukan pengetahuan hukum yang cukup dan ketelitian serta tanggung jawab yang tinggi. Untuk itu dalam praktek sehari-hari notaris diwajibkan untuk senantiasa menjunjung tinggi hukum dan asas negara serta bertindak sesuai dengan makna sumpah jabatan dan mengutamakan pengabdiannya kepada kepentingan masyarakat dan negara. Adanya kewajiban kepribadian yang baik dan tuntutan untuk menjunjung tinggi martabat jabatan notaris, dengan demikian dalam pelaksanaan jabatannya notaris tidak dibenarkan melakukan hal-hal dan/atau tindakan yang tidak sesuai dengan martabat dan kehormatan jabatan notaris.

Penyuluhan hukum atau penjelasan mengenai ketentuan undangundang ini diberikan dalam rangka membantu dalam pembuatan akta yang diperlukan dan ini merupakan suatu kesatuan yang tidak dapat dipisahkan satu dengan yang lainnya. Nasihat yang harus diberikan oleh seorang notaris harus berdasarkan keyakinan dalam bidang yang dikuasai dan dalam batasbatas kemampuannya. Keahlian hukum dalam bidangnya harus sesuai dengan peraturan perundang-undangan yang berlaku. Dengan adanya penyuluhan hukum yang diberikan oleh notaris, diharapkan para penghadap yang memerlukan bantuannya menjadi paham dan mengerti mengenai keputusan yang terbaik yang akan 
diperbuatnya dan juga sebelum notaris membuatkan akta yang diinginkan oleh kliennya, notaris harus terlebih dahulu memberikan suatu penjelasan mengenai keadaan hukum yang sebenarnya kepada klien, hak dan kewajiban mereka masing-masing, agar klien tersebut mengerti akan keadaan yang sebenarnya.

\section{Tanggung Gugat Notaris Atas Penyuluhan Hukum Yang Merugikan Para Pihak}

Notaris sebagai lembaga negara yang independen adalah subyek hukum, sebagai pendukung hak dan kewajiban hukum, yang memiliki kedudukan hukum yaitu sebagai kepanjangan tangan dari pemerintah yang melayani kebutuhan masyarakat dalam pembuatan akta otentik. Sebagai subyek hukum Notaris dapat melakukan perbuatan hukum, yaitu perbuatan yang ada relevansinya dengan hukum atau perbuatan yang dapat menimbulkan akibat hukum. Dengan demikian, setiap bentuk dari perbuatan hukum, secara pasti akan menimbulkan akibat hukum baik yang positif maupun yang negatif. Akibat hukum yang negatif memiliki relevansi dengan tanggung-gugat karena dapat memunculkan tuntutan dari pihak yang terkena akibat hukum yang negatif yang biasa menimbulkan kerugian dari pihak tersebut.

Tanggung jawab notaris di dalam UUJN dimaksudkan sebagai keterikatan notaris terhadap ketentuan-ketentuan hukum dalam menjalankan tugas dan kewajibannya, dalam pengertian bahwa semua perbuatan notaris dalam menjalankan tugas kewajibannya harus dapat dipertanggungjawabkan secara hukum, termasuk dengan segala konsekuensinya untuk dikenakan sanksi hukum terhadap pelanggaran normanorma hukum yang mendasarinya
(Ghansham Anand;2013). Tanggunggugat (liability/aansprakelijkheid) merupakan bentuk spesifik dari tanggungjawab. Pengertian tanggunggugat merujuk kepada posisi seseorang atau badan hukum yang dipandang harus membayar suatu bentuk kompensasi/ganti rugi setelah adanya peristiwa hukum atau tindakan hukum (Peter Mahmud Marzuki ;2009).

Menurut J. H. Nieuwenhuis, tanggung gugat timbul karena adanya perbuatan melanggar hukum (onrehtmatige daad) dan merupakan penyebab (oorzaak) timbulnya kerugian sedangkan pelakunya bersalah (schuld) maka orang itu harus bertanggung gugat atas kerugian tersebut (J. $H$. Nieuwenhuis;1985;118). Selanjutnya Y. Sogar Simamora menyatakan bahwa inti dari suatu perbuatan melanggar hukum (onrechtmatige daad), yaitu tidak ada hubungan kontraktual antara satu pihak dengan pihak lainnya. Perbuatan melanggar hukum dapat terjadi bila salah satu pihak merugikan pihak lain dengan suatu kesengajaan ataupun ketidaksengajaan dan menimbulkan kerugian pada salah satu pihak (Ghansham Anand, Ibid).

Munir Fuady menyatakan bahwa teori aansprakelijkheid atau dalam bahasa Indonesia dapat disebut dengan teori tanggung gugat adalah teori untuk menentukan siapa yang harus menerima gugatan atau siapa yang harus digugat karena adanya suatu perbuatan melawan hukum. Jadi tanggung gugat terhadap notaris timbul karena adanya kesalahan yang dilakukan di dalam menajalankan tugas jabatan dan kesalahan itu menimbulkan kerugian terhadap penghadap atau orang lain. Dapat dikatakan secara sedarhana bahwa setiap kewenangan yang sah baik yang bersumber dari undang-undang maupun dari perjanjian, dapat 
menimbulkan tanggung jawab pada si pelaksana tugas atau kewajiban itu (Munir Fuady;2002).

Dalam kaitannya dengan penyuluhan hukum yang diberikan oleh Notaris yang kemudian merugikan para pihak maka pihak yang dirugikan dapat menuntut ganti kerugian kepada notaris, apabila memenuhi unsur-unsur sebagai berikut : 1) Adanya suatu perbuatan, yaitu bahwa suatu perbuatan melawan hukum selalu diawali oleh suatu perbuatan dari si pelakunya. 2) Perbuatan tersebut melawan hukum, yaitu perbuatan yang : a) melanggar undang-undang yang berlaku; b) melanggar hak orang lain yang dijamin oleh hukum; d) bertentangan dengan kewajiban hukum si pelaku; e) perbuatan yang bertentangan dengan kesusilaan; f) bertentangan dengan kehati-hatian atau keharusan dalam pergaulan masyarakat yang baik. 3) Adanya kesalahan dari pihak pelaku,yaitu bahwa suatu tindakan dianggap oleh hukum mengandung unsur kesalahan jika memenuhi unsurunsur sebagai berikut : a) ada unsur kesengajaan; b) ada unsur kelalaian; c) tidak ada alasan pembenar atau alasan pemaaf, seperti keadaan memaksa (overmacht), membela diri, tidak waras, dan lain-lain. 4) Adanya kerugian bagi korban yaitu kerugian karena perbuatan melawan hukum meliputi kerugian materiil dan immaterial, yang juga dinilai dengan uang. 5) Adanya hubungan kausalitas, yaitu hubungan kausal atau sebab akibat yang dimaksud adalah dengan adanya perbuatan yang dilakukan seseorang dapat mengakibatkan pihak lain menderita kerugian (Munir Fuady;2002).

Berkaitan dengan hubungan kausalitas terdapat 2 (dua) teori, yaitu : 1) Conditio Sine Qua Non, menurut teori ini, setiap orang yang melakukan perbuatan melanggar hukum selalu bertanggung gugat, jika perbuatannya condition sine qua non menimbulkan kerugian. 2) Adequate Veroorzaking, menurut teori ini, si pelaku hanya bertanggung gugat atas kerugian yang merupakan akibat daripada perbuatan melanggar hukum yang secara layak dapat diperkirakan timbul (Munir Fuady;2002).

Pembuatan akta notaris baik akta relaas maupun akta pihak, yang menjadi dasar utama atau inti dalam pembuatan akta notaris, yaitu harus ada keinginan atau kehendak dan permintaan dari para pihak, jika keinginan dan permintaan para pihak tidak ada, maka notaris tidak akan membuat akta yang dimaksud. Untuk memenuhi keinginan dan permintaan para pihak tersebut, notaris dalam hal ini mempunyai kewenangan untuk dapat memberikan penyuluhan hukum sehubungan dengan pembuatan akta yang bersangkutan, dengan berdasarkan kepada peraturan perundang-undangan yang berlaku.

Pada saat saran atau penyuluhan hukum dari notaris tersebut diikuti oleh para pihak dan dituangkan atau dilanjutkan dengan pembuatan aktanya, dan ternyata akta notaris tersebut dikemudian hari bermasalah atau menimbulkan kerugian bagi salah satu pihak dalam akta, maka dalam hal ini notaris tidak bisa langsung dipersalahkan atau diminta pertanggung jawabannya, karena akta notaris tersebut adalah merupakan keinginan dan permintaan para pihak, bukan saran atau pendapat notaris, melainkan isi akta merupakan perbuatan para pihak dan bukan perbuatan atau tindakan notaris. Notaris hanya memformulasikan keinginan para pihak agar tindakannya dituangkan dalam bentuk akta otentik atau akta notaris. Pihak yang merasa dirugikan dan yang 
hendak menuntut notaris tersebut terlebih dahulu harus dapat membuktikan beberapa hal berikut ini : a) Adanya derita kerugian; b) Antara kerugian yang diderita dan pelanggaran atau kelalaian dari notaris terdapat hubungan kausal; c) Pelanggaran (perbuatan) atau kelalaian tersebut disebabkan kesalahan yang dapat dipertanggungjawabkan kepada notaris yang bersangkutan.

\section{Kesimpulan}

Kewenangan Notaris untuk memberikan penyuluhan hukum kepada para pihak yang berkepentingan dalam pembuatan akta autentik adalah dalam bentuk pemberian pemahaman hukum terkait perbuatan hukum yang akan dituangkan ke dalam Akta. Notaris memberikan pemahaman kepada para pihak terkait ketentuan-ketentuan dalam Peraturan Perundang-Undangan yang berhubungan dengan perbuatan hukum yang akan dilakukan oleh para pihak meliputi penjelasan mengenai apa saja yang diperbolehkan dalam menerapkan asas kebebasan berkontrak dan apa saja yang menjadi batasannya.

Tanggung Gugat Notaris atas penyuluhan hukum yang merugikan para pihak adalah berupa pemberian ganti rugi. Pihak yang merasa dirugikan dapat menggugat notaris atas dasar perbuatan melawan hukum dengan terlebih dahulu harus dapat membuktikan adanya derita kerugian, adanya pelanggaran atau kelalaian dari notaris yang menyebabkan kerugian dan adanya kesalahan yang dapat dipertanggungjawabkan kepada notaris yang bersangkutan.

\section{Saran}

Perlu dilakukan perubahan terhadap UUJN khususnya untuk memperjelas dan mempertegas kewenangan Notaris dalam memberikan penyuluhan hukum sehubungan dengan pembuatan akta agar tidak terjadi multitafsir dan mampu memberikan kepastian hukum.

Notaris diharapkan dapat menjalankan tugas jabatan secara profesional dan memiliki pengetahuan serta keilmuan yang mumpuni di bidang hukum, khususnya pemahaman mengenai Peraturan PerundangUndangan yang berlaku di Indonesia sehingga mampu memberikan penyuluhan hukum yang tepat bagi para pihak yang akan membuat akta dan tidak terjadi kerugian bagi para pihak dari adanya penyuluhan hukum tersebut

\section{Daftar Pustaka}

\section{Buku-Buku}

Departemen Pendidikan Dan Kebudayaan, Kamus Besar Bahasa Indonesia, Balai Pustaka, Jakarta, 1985

Habib Adjie, Meneropong Khasanah Notaris Dan PPAT Indonesia, Citra Aditya Bakti, Bandung, 2009

J. H. Nieuwenhuis, Hoofdstukken Verbintenissenrecht, Terjemahan Djasadin Saragih, Tanpa Penerbit, Surabaya, 1985

Munir Fuady, Perbuatan Melawan Hukum, Citra Aditya Bakti, Bandung, 2002

Peter Mahmud Marzuki, Pengantar Ilmu Hukum, Kencana Prenada Media Grup, Jakarta, 2009

Rusdianto Sesung, dkk., Hukum Dan Politik Hukum Jabatan Notaris, R.A. De Rozarie, Surabaya, 2017

Tan Thong Kie, Studi Notariat-Serba Serbi Praktek Notaris, Ichtiar Baru Van Hoeve, Jakarta, 2000

\section{Jurnal, Makalah Dan Karya Ilmiah}

Abdullah,"Presentasi Dalam Penyuluhan Hukum", Makalah, diunduh dari www.bphn.go.id 
Ghansham Anand, "Karakteristik Jabatan Notaris Di Indonesia Dan Batas Tanggung Gugatnya", Disertasi, Program Studi Doktor Ilmu Hukum, Fakultas Hukum Universitas Airlangga, Surabaya, 2013

Guntur Iskandar, "Kekuatan Pembuktian Akta Di Bawah Tangan Yang Disahkan Dan Dibukukan Oleh Notaris", Jurnal Yustisia Universitas Andalas, Vol. 22 No.1 Tahun 2013

Hatta Isnaini Wahyu Utomo, "Pelaksanaan Tugas Jabatan Notaris : Bahan Diskusi Dalam Persiapan Menghadapi Ujian Kode Etik Notaris", Makalah, disampaikan pada acara Belajar Bareng Alumni, Universitas Narotama Surabaya, Februari 2018 Herlien Budiono, "Asosiasi Notaris, Suatu Jalan Keluar?", Media Notariat, No.2/Tahun I, Oktober, 1999

Laurensius Arliman S, "Kewajiban Notaris Dalam Pemberian Penyuluhan Hukum Kepada Masyarakat Berdasarkan UndangUndang Nomor 2 Tahun 2014 Tentang Perubahan Atas UndangUndang Nomor 30 Tahun 2004 Tentang Jabatan Notaris", Makalah, diunduh dari www.researchgate.net

Nofiardi, "Membangun Hukum Indonesia Yang Progresif", Jurnal Advokasi Sekolah Tinggi Ilmu Hukum Padang, Vol. 6 No. 1 Edisi Juni-Desember 2015

Ririk Eko Prasetyo, M.Khoidin Dan Ermanto Fahamsyah, "Makna Pemberian Penyuluhan Hukum Oleh Notaris Pembuatan Akta Menurut Undang-Undang Jabatan Notaris", Jurnal Lex Humana,Volume 1, Nomor 1, Oktober 2016
Roenastiti Prayitno, "Tugas dan Tanggung Jawab Notaris sebagai Pejabat Pembuat Akta", Media Notariat, No.12-13/Tahun IV, Oktober 1989

Sudjito, "Critical Legal Stidies (CLS) dan Hukum Progresif Sebagai Alternatif Dalam Reformasi Hukum Nasional dan Perubahan Kurikulum Pendidikan Hukum", Jurnal Ultimatum Sekolah Tinggi Ilmu Hukum Iblam, Vol. 2, Edisi September 2008 